\title{
MODEL OF LEARNING COGNITIVE MORAL DEVELOPMENT THROUGH PICTORIAL STORY IN ELEMENTARY SCHOOL
}

\author{
Risa Wismaliya ${ }^{1 *}$, Kama Abdul Hakam ${ }^{2}$, Mubiar Agustin $^{3}$ \\ ${ }^{1}$ S.Pd., Universitas Pendidikan Indonesia, INDONESIA, wismaliyarisa@gmail.com \\ ${ }^{2}$ Dr., M.Pd, Universitas Pendidikan Indonesia, INDONESIA, kama.hakam@gmail.com \\ ${ }^{3} \mathrm{Dr}$., M.Pd., Universitas Pendidikan Indonesia, INDONESIA, mubiar@upi.edu \\ ${ }^{*}$ Corresponding author
}

\begin{abstract}
One of learning model in character education that raised constructive value is cognitive moral development (cmd). This model (cmd) has a special characteristic syntax, which is moral dilemma. The moral dilemma is made by the teacher in a dilemma story that is presented to the student as a stimulus to make students feel in a dilemmatic situation. Students must choose one option from two options presented. The choice is not about right and wrong but focus on point of the student's reason what they chose. The students' choice in the moral dilemma shows the stages of students' moral development that developed by kohlberg from the pre-conventional, conventional and post-conventional stages, which have 6 stages. The study was conducted on $5^{\text {th }}$ graders of elementary school, so that only 4 stages applied of 6 stages of moral development. Characteristics of elementary school student between 10-12 years classified as concrete operational stage (Jean Piaget, 1983), it's result the moral dilemmas that are displayed not only in the form of a flowing dilemmatic story but need a connection thoughts through the picture. The pictorial story contain with moral dilemmas will be displayed with some pictures that repserent the meaning purpose of the story to facilitate the students in digesting the meaning of the story moral dilemmas content. There are 3 situations that are presented in one moral dilemma story. First picture is introduction story which describe the situation (at school / home / play environment). Second picture is contains of dilemma conflict situation which directing to the third picture, it's "confusion" as a symbol of dilemma between choosing two choices. The finding of this study is after the students read the pictorial story with moral dilemma then the students fill out the evaluation sheet in the form of Defining Issues Test (essay closed) from James Rest to know their level of moral development (stage 1-4). This method of research used experiments with classes that are given treatment through pictorial story media and control classes that are not given treatment. The results of this study indicated a higher change in the students' moral reasoning rather than control class.
\end{abstract}

Keywords: Cognitive moral development, moral dilemmas, pictorial story, stage of moral development.

\section{INTRODUCTION}

Based on some researchs in Moral Education, it shows that the importance of guidance and moral development of students from an early age in the form of construction model value, as developed by Cognitive Moral Development model initiated by Lawrence Kohlberg (1958 and 1975; Hakam, 2008a, 
Hakam, 2017b; Setianingsih, 2017), because the tradition of fostering the character of students who have been done in the Indonesian schooling through the approach of value transmission, that is the inheritance of value through model training, modeling, conditioning and habituation only foster certain character of the character that is getting the child to accept and implement the values noble is taught, so that learners are directed to be a person who is obedient, disciplined, and submissive. However, such learners are particularly vulnerable when confronted with value conflicts, individuals who receive such character education are often unable to resist temptation and ultimately take erroneous action because their moral considerations are rarely honed. Therefore, Character Education rooted in Durkheim's sociological thoughts should be juxtaposed together with Moral Education which is rooted in Piaget's psychological thoughts which emphasizes moral cognitive development. (Snarey in Nuccy, 2008).

The results of Setiyaningsih dissertation (2017) study recommends the need for creative teachers in developing the Cognitive Moral Development model in Elementary Schools in preparing moral dilemmas that are more suited to the cognitive development stages of the students because the use of a moral dilemma with a purely moral dilemma story is less able to significantly increase moral judgment. In line with the results of this study, Samuelson's (2007) study showed that discussion-based curriculum utilizing film cliches containing the moral dilemma of popular Hollywood films resulted in a significantly increased moral judgment compared with non-participating students. In line with the findings of this study Hakam (2017) recommends the need to research how the development of moral dilemmas as a medium of moral learning in elementary school students who think is still in concrete phase so that the original moral dilemma hypochesis hypothesis becomes more factual in the form of picture story dilemma.

\section{LITERATURE REVIEW}

Reality in Indonesia in value education uses only value transmission culture (inheritance value), and less value development, it can be seen from micro strategy and macro strategy of character education in Indonesia. (Hakam, 2017) In macro terms, character education by Kemendiknas implements three strategies: First through top-down intervention in the form of socialization, regulation, capacity building, implementation and cooperation, monitoring and evaluation; both explore practical experience in the field (bottom-up); the third is revitalization program. Character education process must go through the process of intervention and habituation (Dasim Budimansyah: 2010). Intervention is a process of character education that is done formally, packaged in learning and learning interaction (Learning and intruction) is deliberately designed to achieve the goal of character building by applying a variety of structured learning (Structured learning exsperiences) to include two impacts as well as the impact of instructional (instructional effect) and nurturant effect. Character education in school and at home can be achieved with five strategies (Kusnadi, 2013, p.54). These five strategies include; the cultivation of moral knowledge, creation of the environment (habituation), conditioning, reinforcement and modeling. Thus, the macro and micro strategy of Character Education in Indonesia uses a tradition of value transmission, which emphasizes inheritance, training, habituation and modeling. This value transmission model is very important in cultivation the value but it is not sufficient enough to prepare the next generation of moral successors. Therefore, it's required a education model that can sharpen and improve moral consideration of student, that is model of cognitive moral development, so that students not only know the value of noble values and can embrace these values but they will be a mature human moral judgment, resistant to temptation, principled not drowned and able to face conflict and moral dilemma with a mature solution (Hakam, 2017)

The Cognitive Moral Development model was developed by Lawrence Kohlberg, a psychologist and philosopher of moral education who had dramatic life experiences, he was often punished in school for rebelling against arbitrary social customs, indirectly continuing studies to the university, but being a ship's sailor Jewish refugees in Europe to establish the state of Israel in Palestine. His experience creates a moral dilemma between obeying authority by upholding human values, or obeying the rules or helping the afflicted. When entering college, these dilemmas affect his work. Cognitive dilemma occurs when the norms, values and moral lessons received through the enculturation process no longer match or collide with other ideal frameworks that may be more suited to experience, so whether we stick to values that are valued or changed at a more appropriate new value?. The theoretical framework of Lawrence Kohlberg was influenced by Jean Piaget's work on cognitive development (1896-1980) and Emile Durkheim on Moral Education (1856-1917) thus structuring and refining it into the theory of Cognitive moral development (Nucci, 2008). And at the age of 31 he completed his doctorate in psychology and philosophy by interviewing 84 teenagers in Chicago about the moral dilemma. Finally he found the theory of six stages of structured cognitive moral considerations as Nucci (2016, hlm.4) said that "Development beyond adolescence in moral thinking is in two forms: (1) the gradual application of morality in broader adult contexts, and (2) the result of social discourse and progressive readjustments at the individual and societal level of views of the morality of societal practices". The first stage is Preconventional level. This stage has two levels (stage), there are: 


\section{Stage 1: The Punishment and Obedience Orientation}

Children at this stage find it difficult to consider two points of view in a moral dilemma. As a result, they ignore the intentions and intentions of others, and instead they focus on fear of authority and avoid punishment as an excuse for moral action. In this situation, "moral notions are directed to concrete places or events" (Dumon 1988: 15). The morality of this stage requires a physical understanding of moral authority, the example "Father is the Boss because he is greater" (Kohlberg, 1984, p.624).

\section{Stage 2: The Instrumental Purpose Orientation}

At this level the realization that people have different perspectives in a moral dilemma begins to emerge, but this understanding is still concrete. Individuals consider good action as something that satisfies their needs, and they believe that others also act because of their personal interests. Reciprocity is understood as a balanced exchange of pleasure, for example in the phrase "You do this for me and I will do it for you". His reasoning runs through a physical appearance to be developed on a psychological perspective, but this view is illustrated on the surface only (not deeply). Kohlberg explains the perspective on stage 2 as follows:: "... pragmatic - to maximize satisfaction of one's needs and desired while minimizing negative consequences to the self. The assumption that the other is also operating from this premise leads to an emphasis on instrumental exchange... for example, it is seen as important to keep promises to insure that others will keep their promises to you and do nice things for you, or...in order to keep them from getting mad at you" (Kohlberg, 1984, p.626-628).

The second stage is the Conventional level and has two levels:

\section{Stage 3: "The good boy-good girl" Orientation, or The Morality of Interpersonal Cooperation}

The desire to fulfill the rules is because they support social harmony beginning to emerge in the context of limited personal bonds. At level 3 these individuals want to retain the affection and approval of their friends and family by "being good people," such as trustworthy, loyal, respectful, helpful, sweet children and so on.

\section{Stage 4: The Social-Order Maintaining Orientation}

At this level the individual takes into account a broader perspective, ie the perspective of the laws of society. The moral choice is no longer dependent on close relationships with others, but rules must be imposed in a one-sided way to everyone, and every member of society has a personal obligation to obey them.

The third stage is Conventional Post. This stage has two levels:

\section{Stage 5: "The Social-Contract Orientation"}

At the fifth level individuals view laws and rules as flexible tools for advancing humanitarian goals. They can imagine alternatives to their social order, and they emphasize fair procedures for interpreting and changing laws when there is a good reason to do so. If the law is consistent with the rights and wants of the majority, then everyone will obey it because of the social contract-orientation of free participation and desire within the system, because it generates better for people than if it does not exist.

\section{Stage 6: "The Universal Ethical Principle Orientation"}

At this stage the right action is defined by personal choice of the ethical principles of the righteous word (consience) for all human beings without regard to law and community agreement. Those values are abstract, not concrete moral rules as in the scriptures. At this sixth level the individual mentions typically these principles as suitable considerations that are the demands of the whole of human life and the respect for the worth of each person.

Lawrence Kohlberg as the initiator of cognitive Moral Development (1976) states that moral education not only teaches students to behave well, but students must have maturity of moral considerations so that the choice is principled on the value that is believed valid. To rsise such students requires a learning model by using a hypothetical moral dilemma and his famous moral dilemma is Heinz's dilemma through the dilemma students are faced with two choices of values, the choice does not determine right or wrong but presents value conflict whose choice requires consideration. Therefore, the main purpose is not on the choice of tesebut but how the consideration given by students on the choice. The more often people face a dilemma and hear people's judgment in the face of a dilemma, the more rapidly increasing the stage of moral judgment and the stage of individual moral judgment can be measured. (Larry Winecoof, 1988).

Briefly, the proportion of Kohlberg's theory of moral development is as follows:

1. Moral development is the result of cognitive reorganization. 
2. Moral development occurs in successive stages.

3. The existence of a series of cultures and moral and social standards that can be used as the foundations internationally in the stages of moral development seen from its moral development.

4. Through the proper process of education the students can be helped to bypass the hierarchy of moral development stages, through which they can increase the maturity of their moral decisions (Larry Winecoof, 1988).

To measure the moral stages of individual judgment, Kohlberg developed a measuring instrument called the Moral Judgment Instrument (MJI), a measure of open interviews whose results were scored. To use it is somewhat complicated and requires quite serious exercise, so it is not easy to use by beginners. (Hakam: 2000). Therefore, the followers of Kohlberg developed more practical measurement instruments, such as James Rest who developed the Defining Issues Test (DIT) in the form of multiple choice. James R. Rest and Darcia Narvaez and Stephen J. Thoma and Muriel J. Bebeau $(2000,4)$ propose models based on moral considerations using the D.I.T. "A model of moral judgment (hereafter the neo-Kohlbergian approach) addressing this issue.Using 25 years of data collected with the Defining Issues Test (DIT)".

DIT can also be used to measure the stages of elementary school students' considerations. Elementary School students, especially in the ability and social and moral skills, are the students' ability to understand the various rules and values in the group and are able to interact with the various groups in harmony. Teachers should be able to guide students to learn to understand, appreciate and care for others around them. (Essence of Education in Elementary School, Agus Taufiq).

Elementary school-aged children are at a concrete operational stage. In that age range the child begins to show the following learning behaviors: (1) Starts viewing the world objectively, shifting from one aspect of the situation to another reflectively and looking at the elements simultaneously, (2) Start thinking operatively, (3) Use operational thinking to classify things, (4) Establish and use simple, simple scientific connectivity, and use causal relationships, and (5) Understand the concept of substance, volume of fluids, length, width, breadth, and weight. (Characteristics of Students in Elementary School Class Low and Learning By: Sekar Purbarini Kawuryan Universitas Negeri Yogyakarta).

To facilitate their understanding of learning media required one of the statues of a pictorial story for children. Children's stories are part of a children's literature that has different construction and content characteristics from adult stories and other stories. A child's story tells the story of a child's life with all aspects of being and influencing them. Various forms of stories are presented to children diverse forms, one of which is a pictorial story. "Illustration that tell a story-usually fiction- can perhaps be grouped in two main categories: those that support or punctuate an existing text and those that are an integral part of the stories in which the words can sometimes adopt a secondary role" (Simpson, 1990, p.98).

The value contained in children's stories can be grouped into personal values and educational value. Personal values relate to emotional development, intellectual development, the development of imagination, the growth of social feeling, the growth of ethical and religious sense. The value of education is related to exploration and discovery, language development, beauty value development, multicultural insight planting and the planting of reading habits (Mulyana, 2011, p.72). Superior children's stories contain personal value and educational value. Children's stories contain personal value if they are able to:

\section{Giving pleasure}

2. Offers narration as a story of reason

3. Developing the imagination

4. Provides a wide range of experiences

5. Developing an inner view of human behavior.

While the story of a child that contains the value of education if able:

1. Develop language skills

2. Develop reading skills

3. Develop the ability to tell stories

4. Support the ability to write

5. Introduce literary riches to children 
The picture story in elementary school is a medium of story accompanied by pictures to clarify the contents of the story and equate the child's area of experience from the stage of child development from Jean Piaget. The concrete operational stage (age 7 or 8-11 or 12 years) to avoid the limitations of children's thinking needs to be given a concrete picture, so that he is able to examine the issue". (Jean Piaget in Cece Rakhmat: 2013). In addition words and images are two interrelated elements that create mutual interanimation together in constructing meaning (Gaiman: 2010). The story is part of the prose type literature. For children's literature, storytelling is reinforced with images. The purpose of image accompaniment in storytelling is to strengthen the story so that children can more easily understand the story. "In addition, the presence of images is one means to attract attention" (Suyatno: 2009, Sarumpaet: 2009, and B. Nurgiyantoro: 2005). In addition through the story, children are brought into the story. Marcia Baghban (2007, p.4) says it in the journal "Classroom materials relevant to the social and cultural experiences of children generate interest in and enthusiasm about learning. When teachers include books about the negotiation of another culture in the curriculum, children learn through reading that stories can be about people like them, that stories of their experiences are worthy of being in a book, and that other children have felt the way they do"

\section{METHODOLOGY}

This study aims to produce a model of moral education in improving the moral judgment of students in elementary schools. Therefore used Research and Development method through:

1) Examines the model of character education learning process that is now happening in elementary school

2) Construct the theoretical conception of Cognitive Moral Development Lawrence Kohlberg model in improving students' moral judgment

3) Find a model of test result of analysis and synthesis of reality model in elementary school with model of Kohlberg Cognitive Moral Development theory adjusted to student characteristic

The research procedure (a) at the preparatory stage is the creation of a moral dilemma to be used in the 5th grade of the elementary school of judge's result of moral education expert, developmental psychology, and linguistic expert (b) defined the syntax of the cmd learning model in the 5th grade of the elementary school (c) conduct a pre test in the experimental and control classes (d) the implementation of the learning in the experimental class with 12 moral dilemmas during one semester (e) evaluation using DIT instruments in the form of multiple chois developed by James Rest.

Moral Dilemma stories contain of five stories with the picture which representative to describe the stories. There are:

\begin{tabular}{|c|c|c|}
\hline CHARACTER & TITLE STORY & PICTURES \\
\hline Honesty & Flower Vase & $\begin{array}{l}\text { 1. Rowdy atmosphere is playing in the classroom. } \\
\text { 2. Flower vase split. } \\
\text { 3. Mrs. Melati present in class. } \\
\text { 4. Mrs. Melati nudge the vase } \\
\text { 5. Mrs. Melati feels guilty } \\
\text { 6. Children dilemma }\end{array}$ \\
\hline Honesty & Rasyid's Book & $\begin{array}{l}\text { 1. Azmi went to school. } \\
\text { 2. Rashid gives homework book with a sick face. } \\
\text { 3. In class, Azmi is confused because the homework book is } \\
\text { missing. } \\
\text { 4. Azmi dilemma between seeing the book homework Rashid } \\
\text { or not }\end{array}$ \\
\hline Cooperation & The Ball & $\begin{array}{l}\text { 1. Children play ball in dry fields. } \\
\text { 2. The ball is thrown at Mr. Imron. } \\
\text { 3. Swipe orange fell and scattered. } \\
\text { 4. The sound of the call to prayer from the mosque. } \\
\text { 5. Children run. } \\
\text { 6. Fahri dilemma. }\end{array}$ \\
\hline Cooperation & Contest of wits & $\begin{array}{l}\text { 1. The atmosphere of the home of llham and Ghifar is fun. } \\
\text { 2. Ilham asks Ghifar not to participate in the quiz contest and } \\
\text { begs to teach his. } \\
\text { 3. In school scout teams get together. } \\
\text { 4. Ghifar appointed race. } \\
\text { 5. Ghifar dilemma think of his brother }\end{array}$ \\
\hline
\end{tabular}




\begin{tabular}{|l|l|l|}
\hline Empathy & Keeping a sister & $\begin{array}{l}\text { 1. Mira practicing chess at home. } \\
\text { 2. Mom and Dad ask Mira to take care of her sick sister. } \\
\text { 3. Mira's sister who lay sick. } \\
\text { 4. Mira is confused because tomorrow will come the chess } \\
\text { trainer to school to train it. }\end{array}$ \\
\hline
\end{tabular}

Example the Moral dilemma stories:

About Honesty

The title: Flower vase

In the morning at class 5, Akbar, Radit and his friends prepare to study. At that time Mrs. Melati has not came to the class yet. Various activities was done by them, playing chase, reading books, some who erase the blackboard and laugh to enjoy togetherness in the classroom. Suddenly, when all students were playing in the class while waiting for the teacher, the vase on Mrs. Melati's table fell to the floor and split in two. All students fell silent and shocked, they saw a vase flower to the front of the class, closer to the table of Mrs. Melati. Akbar as the head of the class did not blame anyone, because all the students did play in the classroom, did not advise each other. Akbar just asks his friends. "How is this? Mrs. Melati must be angry because we are noisy ", all his friends are silent, then Radit proposed "we just glue the vase of this flower vase"."But it will still be discovered by Mrs. Melati" said Annisa. "We just need to dues after school to buy a new one, so tomorrow the nice flower vase will be back" Radit replied and agreed by all classmates. The flower vase was glued by them so the broken vase was not appears. Five minutes later, Mrs. Melati came to the class and sat at her desk. All students feel trembling and fear being caught by their teacher. "My students are smart, sitting neatly when I have not arrived. I like your attitude. I hope you do not make noise when there is no teacher" Praise of Mrs. Melati toward Akbar and his friends. Gradually learning began smoothly, when the Mrs. Melati was writing on the blackboard, she stood up from her chair and knocked over the vase so it split in two back to the floor. With a spry Mrs. Melati took the vase and felt guilty about the incident "Oh my God, I accidentally broke our flower vase, Forgive me" said Mrs. Melati while clearing the vase of flowers and keep it on the table. "Though this flower vase is a gift when our class won the cleanest class contest" Mrs. Melati looks sad with the vase of the flower. Radit, Akbar, Annisa and others can only be silent and upset in the heart. "Do we have to tell that the vase has fallen but Mrs. Melati would be angry" or "we do not talk, tomorrow we will change in the next day"

Instructions for this task:

1. Choose one of the actions that you will do according to the questions below!

2. Choose the reason why you did it! (circled)

From the story of Vase Flower, what would you do if you were a 5th grade who took the responsible broke the vase?

A. "should we tell that the vase has fallen and broken but the Mrs. Melati will be angry"

B. "or we do not talk, we will change tomorrow"

\section{If you choose the $A$, what reason do you choose?}

1. Tell Mrs. Melati the truth for fear of Mrs. Melati angry if knowing the actual events.

2. Notify Mrs. Melati because any friends will tell.

3. As a good student, I will tell the incident to the Mrs. Melati.

4. According to the rules that apply that every person who does must be responsible.

If you choose the $B$, what reason do you choose?

1. Do not tell because Mrs.Melati will angry

2. Do not tell because friends did not do it

3. Do not tell because tomorrow will be replaced vase of interest

4. Not informed because it has been agreed by friends

\section{RESULTS}

\subsection{The Learning Model of Character Education in Elementary School Conducted by Way of}

4.1.1. Is integrated into intra-curricular learning, but the way to integrate it is still inset-folded and not integrated as a program specifically designed and implemented to improve students' moral judgment.

4.1.2. Moral behavior is instilled in the way of life in school life and integrated into extra-curricular activities.

4.1.3. The effort to improve the stage of moral judgment of students is almost never done if there is only a 
moral story is not a dilemma dilemma that asks for moral judgment of students but as an example of good behavior.

4.1.4. The values taught in the form of politeness value, obedience, discipline and religious values.

\subsection{Moral Education Learning Model Using Kohlberg Cognitive Moral Development:}

4.2.1. Develop a credible learning environment, by developing class discussions between students and with teachers, the attendance of students is noticed so as to feel protected and valued.

4.2.2. Preparing and using the moral dilemma of hypotheses as materials and instructional media. The conflict of values present in the dilemma is tested through the process of moral reasoning until students make moral decisions. Each situation is designed to stimulate students' cognitive moral development.

4.2.3. To help students develop moral reasoning process skills by:

(a) Learn the situation

(b) Conducting research to obtain additional information

(c) Consider others from their point of view

(d) Analyze the consequences of any alternative decisions made by people involved in moral dilemma

(e) Setting priority value

(f) Make judgments and moral decisions

4.2.4. To help students learn perspective, ie each character perspective involved in the dilemma by discussing, acting and dramatizing.

\subsubsection{Helping students develop basic communication skills by:}

(a) Listening to others with empathy

(b) Formulate, process, analyze and synthesize information

(c) Make and communicate decisions

(d) Uses and interprets verbal and non-verbal signals

\subsection{Cognitive Moral Development Learning Model through Pictorial Story in Elementary School}

\subsubsection{Preparation Phase}

(a) Preparing the moral dilemma in the form of story dilemma hypothesis that closely related to student life

(b) Develop a moral dilemma hypothesis in the form of pictorial story

(c) Make evaluation in the form of DIT for each moral dilemma

(d) Increase the material of moral dilemma and evaluation format

(e) Integrating moral dilemma materials on the theme of learning, especially with related themes (Language, Social Studies, Civics, Religion)

\subsubsection{Implementation Phase}

(a) Greet students well to make the situation feel familiar

(b) Explain that learning will be discussed among students by discussing the theme that is in pictorial story

(c) Describe the role of each and everyone can express his opinion, and must listen to the opinions of other students. There is no wrong opinion; therefore there is no need to denounce another opinion.

(d) Provide an opportunity for students to change positions if they think like the other person's position

(e) Roleplay in accordance with the moral dilemma in the pictorial story. The teacher attempts to get all the students involved in the role play 
(f) Provide an opportunity for students to express their opinions after changing positions and playing roles

(g) Provide an opportunity for students to determine which values are chosen and what moral considerations are behind the choice

(h) The teacher closes the discussion and role playing sessions by explaining that each person has his or her own choice and has consideration behind that choice.

\subsubsection{Evaluation}

(a) Explain to the students that all options are correct and students must choose one of the options available.

(b) Distribute evaluation format to all students.

(c) Implementation of evaluation.

(d) The teacher examines the results of the evaluation and classifies each student at the stage of moral judgment.

\subsection{The Results of Pre Test and Post Test Phase of Moral Consideration of Grade 5 Students of Elementary School}

4.4.1. The result of pre test in the experimental class and control class shows the stage of moral consideration is relatively the same, the students are in stage 2 to stage 3 .

4.4.2. After being treated for one semester the experimental class shows changes in various moral judgments that are consistent at stage 3 and many students in stage 3 to stage 4 and no longer students are in stage 2. While the control classes there are still students who are at stage 2 to stage 3 and just a few students who are in stage 3 to stage 4.

\section{CONCLUSIONS}

Character Education Model that has been implemented in elementary school using transmission values approach by training, modeling, conditoning and habituation by embedding the noble values agreed upon by the community. Resulting the character of learners who are obedient and courteous, but less develop the moral judgment of students. While the approach of constructivism with the model of Cognitive Moral Development does not do moralization, but rather develop students' reasoning to do legitimate moral judgment so as to develop a person who is principled and resistant to temptation.

The Cognitive Development Model by using moral dilemmas through pictorial story can improve the students' moral judgment than non-treated classes. On that basis, the approach of value transmission and value construction must be carried out simultaneously in elementary school.

\section{REFERENCE LIST}

Baghban, M. (2007). Immigration in Childhood: Using Picture Books to Cope. The Social Studies, 98(2), 7176. https://doi.org/10.3200/TSSS.98.2.71-76

Budimansyah, Dasim. (2011). Penguatan Pendidikan Kewarganegaraan Untuk Membangun Karakter Bangsa. Bandung: Widya Aksara Press.

Damon, W. (1988). Bringing in a New Era in Character Education. Stanford, California : Hoover Institution Press

Gaiman, Neil. 2010, Stardust, New York.Avon

Hakam, Kama Abdul. (2000). Pendidikan Nilai. Bandung: MKDU Press

Hakam, Kama Abdul. 2008. Pendidikan Nilai. Bandung: Value Press.

Hakam, Kama Abdul. 2017. Model of Learning cognitive moral develophment in primary school. Bandung: Reseach for journal International procedings of ADVED (on processing).

Kawuyan, Sekar,. Karakteristik Siswa Sd Kelas Rendah Dan Pembelajarannya [online] 
http://staffnew.uny.ac.id/upload/132313274/pengabdian/KARAKTERISTIK+DAN+CARA+BELAJAR+S ISWA+SD+KELAS+RENDAH.pdf (telah di akases tanggal 28 desember 2017)

Kementrial Pendidikan Nasional. 2011. Strategi Kebijakan Pendidikan Karakter. Jakarta: Badan Penelitian dan Pengembangan Pusat Kurikulum dan Perbukuan

Kohlberg. (1958, 1975). Moral Stage and Moralization, the cognitive development approch. New York: Holt Winehart and Wriston.

Kohlberg. (1984). Phylosophy of Moral Education. Essay on Moral Development. Vol. I \& II. 624. San Francisco: Harper and Raw Publisher.

Kohlberg. (1984). Phylosophy of Moral Education. Essay on Moral Development. Vol. I \& II. 626-628. San Francisco: Harper and Raw Publisher.

Kusnaedi. (2013). Pendidikan Karakter. Bekasi. Duta Media Utama.

Mulyana, Y. (2011). Pendidikan Sastra dan Karakter Bangsa. Bandung : Jurdiksastrasis.

Nuccy, Larry. (2008). Handbook of Moral and Character Education. New York: Routledge.

Nucci, L. (2016). Recovering the role of reasoning in moral education to address inequity and social justice. Journal of Moral Education, 45(3), 291-307. https://doi.org/10.1080/03057240.2016.1167027

Piaget, J. (1983). "Piaget's theory". In P. Mussen (ed). Handbook of Child Psychology. 4th edition. Vol. 1. New York: Wiley.

Rakhmat, Cece, Wismaliya, Risa. (2013). Model Pembelajaran Berbasis Kognitif Moral dalam Upaya Mewujudkan Pendidikan Karakter. Bandung: Proseding Seminar Nasional Pendidikan Dasar 2016.

Rest, J. R., Narvaez, D., Thoma, S. J., \& Bebeau, M. J. (2000). A Neo-Kohlbergian Approach to Morality Research. Journal of Moral Education, 29(4), 381-395. https://doi.org/10.1080/713679390

Samuelson. (2007). Inside the Economist's Mind. Australia: Blackwell Publishing.

Setianingsih, Rarasaning 2017. Pengembangan Model Pembelajaran Berbasis Kognitif Moraldalam Tematik Terpadu untuk Mengembangkan Kognitif Moral Peserta Didik di Sekolah Dasar. Disertasi. Bandung: Prodi Pendidikan Umum Universitas Pendidikan Indonesia.

Simpson, I. 1990. The New Guide to Illustration. New Jersey : Chartwell Books

Suyatno, Sarumpaet, B. Nurgiyantoro. 2009. Menjelajah Pembelajaran Inofatif. Sidoarjo:Masmedia Buana Pusaka.

Taufiq, Agus. (2014). Modul Hakikat Pendidikan di Sekolah Dasar. Dapat diakses : repository.ut.ac.id/4122/1/PDGK4403-M1.pdf

Winecoff, H.L. (1988). Values Education, Learning Package. Fakultas Pasca Sarjana - IKIP Bandung 